\title{
Using Feed Additives to Produce Functional Eggs in Fayoumi Hens
}

\author{
Randa A. Deif Allah ${ }^{1 *}$, M. N. Ali ${ }^{1}$, M. A. F. EL-Manylawi ${ }^{2}$, Ahmed O. Abass ${ }^{2}$ and A. Desouky ${ }^{2}$ \\ ${ }^{I}$ Poultry Nutrition Department, Animal Production Research Institute, Dokki, Giza, Egypt \\ ${ }^{2}$ Department of Animal Production, Faculty of Agriculture, Cairo University, Giza, Egypt \\ *Corresponding author's Email: r_alhndwy55@yahoo.com; (DorCiD: 0000-0003-2992-8745
}

\begin{abstract}
Lately, humans have become more apprehensive about the health and their food relationship. Egg is considered a cheap source of animal protein. Eggs are rich in various essential nutrients that contribute to the quality of human diet. But its cholesterol can contribute to some human serious diseases. The current study examines the hypothesis that assumed addition of antioxidant such as CAX, SS, B or their mixtures to the diet can produce functional egg from Fayoumi hens at late phase of egg production. A number of 168 Fayoumi hens (46weeks of age) were randomly assigned into 8 dietary groups as follows: Basal diet alone or with CAX (6 ppm), SS (0.5 g/kg), B (1 g/kg), $\mathrm{CAX}+\mathrm{SS}, \mathrm{CAX}+\mathrm{B}, \mathrm{SS}+\mathrm{B}$, and $\mathrm{CAX}+\mathrm{SS}+\mathrm{B}$ separately. Forty eight eggs (6 per each group) were analyzed for estimating cholesterol and total antioxidant capacity. Egg of hens fed a combination of CAX+SS+B which had the best total antioxidant capacity value, while the CAX group recorded the best lowest cholesterol value compared to other groups $(\mathrm{P}<0.05)$. It could be concluded that basal diet supplemented with CAX, SS, B alone or with mixture of them may have lowering effect on yolk total cholesterol. This could lead to produce functional eggs which have positive effects on human health and favorable for those suffering from heart syndromes.
\end{abstract}

Key words: Cholesterol, Fayoumi, Functional Egg, Total Antioxidant Capacity

\section{INTRODUCTION}

The native poultry breeds are very highly important for rural economy in developing countries, they are phase of equiponderant agriculture suit that have spirited part in the rural family's food as animal protein exporter (Padhi, 2016). Fayoumi chicken is originally an ancient native breed from the Egyptian cities. Egg considered good quality and cheap source of animal protein. Healthy nutrition has an essential role in reducing the cardiac disease (Khan et al., 2017). Eggs are rich in various essential nutrients that contribute to the quality of human diet. The yolk contains high ranges of both cholesterols and unsaturated fatty acids (Huang et al., 2019). Egg cholesterol is a major dietary cholesterol source (Ylilauri et al., 2017). A high serum cholesterol concentration is a known risk factor for dementia (Deckers et al., 2015), cardiovascular diseases (Nelson, 2013) and Alzheimer disease (Altman and Rutledge, 2010). Many researches focused on functional food, lately Sireesha and Prasanna (2019) made a brief overview about the poultry meat and eggs as functional food.

Hen age and nutrition influenced on the cholesterol values of chicken eggs. Betaine (Trimethylglycine) most Common sources of B are Sugar beet and their by-products (Eklund et al., 2005), naturally occurring component, which is widely distributed in many plants and animal tissues. It plays several roles in body one of the hopeful medications for improving the physiological systems protection mechanisms against oxidative stress (Ganesan et al., 2010). it classfied as anti-oxidant, where it's the metabolism (Zhang et al., 2016), enhanced lipase activity (Zou et al., 1998), it is referred to as 'carcass modifier' (Ratriyanto et al., 2009), promote small intestine osmoregulation (Kettunen et al., 2001). Dietary betaine straight utilized as methyl group donor (Kidd et al., 1997). Canthaxanthin (CAX) a red-orange carotenoid naturally occurring pigment is present in bacteria, algae and some fungi (Esatbeyoglu and Rimbach, 2017), is commonly added to the diets of poultry. One of feed additive used to resist oxidative stress caused by numerous factors including but not fixed to high temperatures (Ma et al., 2005). Sulphate (SS) has an encouraging effect on laying hens production at late period of age (Ali et al., 2007, 2012, 2018). Sulfate groups can be identified as antioxidant (Huang et al., 2005). Several researchers have examined antioxidant properties of tested material as feed additives.

Therefore, the objective of this research was to study the influences of B, SS and CAX alone or as a combination supplemented to the diet on egg cholesterol and total antioxidant of aged Fayoumi laying hens.

\section{MATERIALS AND METHODS}

Ethical approval

The present experiment was carried out at EL-Azab Poultry Research Station, EL-Fayoum Governorate, Egypt 
during the period of $8^{\text {th }}$ January to $8^{\text {th }}$ April, 2018. The chemical analyses were performed in the Laboratories of Poultry Cellular and Molecular Physiology, Department of Animal Production, Faculty of Agriculture, Cairo University, Giza, Egypt. The experimental protocols were approved and carried out according to the regulation and guidelines set by Cairo University Ethics Committee for the Care and Use of Experimental Animals in Education and Scientific.

\section{Treatment groups}

One hundred and sixty-eight Fayoumi hens, 42-weeks-age, were selected and housed individually in single cages. Birds were randomly distributed into 8 treatment groups (18 hens per group), where all groups had almost the same averages of body weight and egg production rate, at the beginning of the experiment. The experimental basal diets were calculated to meet the requirements recommended from the MAD (1996) as given in table 1. Birds from 46-54 weeks of age, in each treatment group were assigned to one of the following dietary supplementations: Control without supplementation, CAX (6 ppm), SS (5 g/kg), B (1 g/kg), CAX+SS, CAX+B, SS+B, and CAX+SS+B. Artificial light was used to provide 16 hours daily photoperiod and the water was available ad libitum, while feed was restricted at 100 g/hen/day. Eggs were collected and recorded every day.

Table 1. Composition and calculated analysis of the experimental basal diets used in the feeding trial

\begin{tabular}{lc}
\hline Ingredients & $\mathbf{k g}$ \\
\hline Yellow corn & 647.5 \\
Soya bean 44\% & 219.0 \\
Wheat bran & 29.0 \\
Limestone & 85.0 \\
Salt & 3.0 \\
Premix* & 4.0 \\
Mono calcium Phosphate & 12.1 \\
DL methionine & 0.50 \\
Total & 1000
\end{tabular}

\section{Calculated analysis**}

CP (\%)

$\mathrm{ME} \mathrm{Kcal/kg}$

Crude fiber (\%)

Crude fat $(\%)$

Calcium (\%)

${ }^{\bar{T}}$ The premix (Vit. \& Min.) was added at a rate of $4 \mathrm{~kg}$ per ton of diet and supplied the following per kg of diet (as mg or gm or I.U. per kg of diet): Vit. A 15000000 I.U., Vit. D3 4000000 I.U., Vit. E 80000 mg, Vit. K3 4000 mg, Vit. B1 2200 mg, Vit. B2 12000 mg, Vit. B6 5500 mg, Vit. B12 20 mg, Niacin $40000 \mathrm{mg}$, Biotin $300 \mathrm{mg}$, Pantothenic acid $20000 \mathrm{mg}$, Folic acid $1500 \mathrm{mg}$, choline chloride $1000 \mathrm{gm}$, Mnganese $100 \mathrm{gm}$, copper $10 \mathrm{gm}$, Se 0.3 gm, Iodine $2 \mathrm{gm}$, iron $60 \mathrm{gm}$ and Zinc $80 \mathrm{gm}$. ** DL methionine: essential amino acid; CP: Crude protein; ME: Metabolizable energy. ${ }^{* * *}$ According to feed composition tables for animal and poultry feedstuffs used in Egypt (2001).

\section{Egg biochemical assay}

Total number of 48 eggs ( 6 eggs from each group) were collected (at the end of 54 weeks of age) to determine the egg quality traits. After measuring egg quality and yolks separated from albumen and then analyzed to measure egg yolk TAOC and total cholesterol were determined calorimetrically by using commercial diagnostic kits and spectrophotometer (model, GBC906 AA), following the same steps as described by manufactures. Samples from the broken were extracted according to the method of Folch et al. (1957).

\section{Statistical analysis}

Data were analyzed using one-way analysis of variance. The statistical analysis was computed using the General Linear Models (GLM) procedure in SAS program (SAS Institute Inc., 2011). The significant differences among 8 treatment groups (Control, CAX, SS, B, CAX+SS, CAX+B, SS+B and CAX+SS+B) for all parameters were separated by Duncan's Multiple Range test. The significance level was set at $\mathrm{P}<0.05$. Results are expressed as Least square means LSM \pm SEM. 
Effects of dietary supplementation eggs cholesterol and total antioxidant concentration in the yolk Fayoumi laying hens at late phase of egg production are shown in table 2. In respect of yolk cholesterol concentration, the highest level with significantly different recorded by hen fed control group $(210.86 \mathrm{mg} / 100 \mathrm{~g})$. However, the lowest significant value recorded in CAX group $(89.58 \mathrm{mg} / 100 \mathrm{~g})$. Hen age influenced on the cholesterol values of chicken eggs (Zemkova et al., 2007). Jiang and Sim (1991) found an increasing cholesterol level with age (mg/egg), also Shafey et al. (1998) found a positive correlation between the cholesterol concentration $(\mathrm{mg} / \mathrm{g}$ yolk) and the hen's age. Sulphate alone or in combination with CAX significantly reduced egg yolk cholesterol and these results agree with those find by Ali et al. (2012). These finding may be due to the effect of CAX and SS components on lipid metabolism. From these results, it could be concluded that CAX may have lowering effect on total cholesterol in the yolk. This could lead to produce enriched eggs that are healthier for human consumption and beneficial for those suffering from heart diseases. Regarding B effect data showed that B group recorded (134.52 versus 210.86) $\mathrm{mg} / 100 \mathrm{~g}$ this may be due to epigenetic effect of B as methyl donor alter methylation profiles of chicken lipoprotein lipase (LPL) gene, moreover it reduces mRNA level of lipogenesis genes and on promoter CpG methylation of fatty acid synthase (FAS) gene in laying hens (Xing et al., 2009 and 2012). Effect of B may be extending to progeny through egg. Idriss et al. (2018) indicated that feeding B to the hens modifies hypothalamic expression of genes complicated in cholesterol metabolism and brain tasks in F1 cockerels through modification of promoter DNA methylation. Hu et al. (2015) indicated that epigenetic mechanisms including DNA and histone methylations can regulate hepatic cholesterol metabolism in chicks by in ovo injection of B. Data in table 2 indicated that egg total antioxidant capacity of Laying hen eggs fed diet supplemented by B + CAX + SS group was superior over all other groups were contain considerable amount of total antioxidants. This superiority was significantly highest over most groups (except those supplemented with CAX or SS. On the other hand, the hen fed control group holed the lowest value with insignificantly difference with those fed B with both CAX and SS groups. This may be attributed to the complementary action or synergism between additives. Each of feed additive alone had positive effect on egg yolk TOAC this approved by Surai (2012) reported that TAOC of egg is influenced by maternal diet antioxidant content. Also results agree with those obtained by Johnson (2013) who reported that antioxidant properties of CAX are apparent in both eggs and chicks of hens supplemented with CAX. Putting in mind that CAX is deposited into the yolk of the egg when it supplemented to broiler breeder hens (Surai et al., 2003). The same trend was found by Zhang et al. (2011) enrichment egg yolk with CAX was associated with a significant improvement of TOAC. This better anti oxidative status of egg yolk might be important for the development of the embryo; rather, egg nutrients act as the 'enhancer' of antioxidant defense against range of diseases. Sulphate alone or in combination with CAX significantly increases TOAC and these results agree with those found by (Ali et al., 2012). Considerable amount of B identifies in Chicken eggs (Zeisel et al., 2003), it could work as anti-oxidant (Zhang et al., 2016). Egg rich in antioxidants and low cholesterol may play a critical role in human health also lower risk Chronic and endemic diseases.

Table 2. Effects of dietary treatment on yolk characteristics of Fayoumi layers at late phase of egg production

\begin{tabular}{lcc}
\hline Treatments & Yolk cholesterol (mg/100g) & Yolk total antioxidant capacity \\
\hline Control diet & $210.86^{\mathrm{a}}$ & $0.404^{\mathrm{c}}$ \\
$\mathrm{CAX}$ & $89.59^{\mathrm{c}}$ & $0.507^{\mathrm{ab}}$ \\
$\mathrm{Na}_{2} \mathrm{SO}_{4}$ & $134.52^{\mathrm{abc}}$ & $0.501^{\mathrm{ab}}$ \\
Betaine & $116.67^{\mathrm{bc}}$ & $0.409^{\mathrm{bc}}$ \\
Betaine+CAX & $169.94^{\mathrm{ab}}$ & $0.404^{\mathrm{c}}$ \\
Betaine+$+\mathrm{Na}_{2} \mathrm{SO}_{4}$ & $175.59^{\mathrm{ab}}$ & $0.409^{\mathrm{bc}}$ \\
$\mathrm{CAX}+\mathrm{Na}_{2} \mathrm{SO}_{4}$ & $147.32^{\mathrm{abc}}$ & $0.411^{\mathrm{bc}}$ \\
Betaine+ $\left(\mathrm{CAX}_{+} \mathrm{Na}_{2} \mathrm{SO}_{4}\right)$ & $176.19^{\mathrm{ab}}$ & $0.544^{\mathrm{a}}$ \\
$\pm \mathrm{SEM}$ & 24.49 & 0.031 \\
$\mathrm{P}$ value & 0.0001 & 0.0001 \\
\hline a,b,c,d; Means within a column with different superscripts differ significantly $(\mathrm{P}<0.0001)$ For each word or item that are required to explanation $* \mathrm{P}<$
\end{tabular}

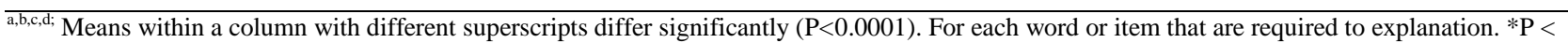
0.0001. CAX: Canthaxanthin'2 Sodium Sulphate; SEM: Pooled Stander Error Means.

\section{CONCLUSION}

It can be demonstrated that supplementation of betaine, canthaxanthin and sodium sulphate or their mixtures in Fayoumi laying hens diets reduce the cholesterol composition and improve total antioxidant capacity of egg yolk and consequently produce healthier egg from Fayoumi aged hen. 


\section{DECLARATIONS}

\section{Authors' Contribution}

Randa A. Dief Allah was responsible for data collection, data analysis, and manuscript writing. M. N. Ali designed the study, drafted and revised the manuscript. M. A. F. EL-Manylawi responsible for scientific material collection, shared in drafted and revised the manuscript. Ahmed O. Abass was responsible for laboratory analysis. A. Desouky shared in samples collection and interpretation of data. All authors read and approved the final manuscript.

\section{Competing interests}

The authors declare that they have no competing interests.

\section{Acknowledgements}

The authors would like to thank Abdel-Rahman M. M. Atta (Professor of Poultry Immunology, Cairo University) for his technical support during this study. The authors are very grateful to Prof. Dr.Sabbah Farouk Youssef (Chief Researcher of Poultry physiology, APRI, ARC.), for her assistance in sample preparation and monitoring of birds throughout the experimental period.

\section{REFERENCES}

Ali M N, Hassan MS and El-Ghany FA (2007). Effect of strain, type of natural antioxidant and sulphate ion on productive, physiological and hatching performance of native laying hens. International Journal of Poultry Science, 6(8):539-554. Available at: https://scialert.net/abstract/?doi=ijps.2007.539.554.

Ali M N, Hassan MS, El-Ghany FA and Nasra B Awadein (2012). Using natural antioxidants with or without sulphate to improve productive and Reproductive Performance of two local strains at late egg production Period. International. Journal. of Poultry Science, 11(4):269-282. at: DOI: https://doi.org/10.3923/ijps.2012.269.282

Ali MN, Hassan MS, Attia KhM, El-Deep MH, Abd El-Ghany FA and Nasra B Awadein (2018). Effect of tyrosine, tryptophan and canthanthin either alone or in combination on productive performance of Egyptian developed laying hens in post-peak egg production period, in presence or absence of sodium sulphate. Egypt. Poultry Science, 38: 981-998. Available at: http://epsj.journals.ekb.eg/article_23238.html.

Altman R and Rutledge JC (2010). The vascular contribution to Alzheimer's disease. Clinical Science, $119(10)$ : 407-421. DOI: https://doi.org/10.1042/CS20100094

Deckers K, van Boxtel MP, Schiepers OJ, de Vugt M, Munoz Sanchez JL, Anstey KJ and Ritchie K (2015). Target risk factors for dementia prevention: a systematic review and Delphi consensus study on the evidence from observational studies. International journal of geriatric psychiatry, 30(3): 234-246. DOI: https://doi.org/10.1002/gps.4245.

Eklund M, Bauer E, Wamatu J and Mosenthin R (2005). Potential nutritional and physiological functions of betaine in livestock. Nutrition Research Reviews, 18:31-48. DOI: https://doi.org/10.1079/NRR200493.

Esatbeyoglu T and Gerald R (2017). Canthaxanthin: from molecule to function. Molecular Nutrition and Food Research, 61(6): 1-17(1600469). Available at: https://doi.org/10.1002/mnfr.201600469.

Feed Composition Tables for Animal and Poultry Feed Stuffs Used in Egypt (2001). Technical bulletin No.1, central lab for feed and food, Ministry of Agriculture, Egypt.

Folch J, Lees M and Stanley GS (1957). A simple method for the isolation and purification of total lipids from animal tissues. Journal of biological chemistry, 226(1): 497-509. Available at: https://www.jbc.org/content/226/1/497.long

Ganesan B, Buddhan S, Anandan R, Sivakumar R and AnbinEzhilan R (2010). Antioxidant defense of betaine against isoprenaline-induced myocardial infarction in rats. Molecular Biology Reports, 37:1319-1327. DOI: https://doi.org/10.1007/s11033-009-9508-4.

Hu Y, Sun Q, Li X, Wang M, Cai D, Li X and Zhao R (2015). In ovo injection of betaine affects hepatic cholesterol metabolism through epigenetic gene regulation in newly hatched chicks. PloS one, 10(4):e0122643. DOI: https://doi.org/10.1371/journal.pone.0122643. eCollection 2015.

Huang J, Hao Q, Wang Q, Wang Y, Wan X and Zhou Y (2019). Supplementation with green tea extract affects lipid metabolism and egg yolk lipid composition in laying hens. The Journal of Applied Poultry Research, 28(4):881-891. DOI: https://doi.org/10.3382/japr/pfz046.

Huang R, Mendis E and Kim SK (2005). Factors affecting the free radical scavenging behavior of chitosan sulfate. International journal of biological macromolecules, 36(1-2): 120-127. DOI: https://doi.org/10.1016/j.ijbiomac.2005.05.001.

Idriss AA, Hu Y, Hou Z, Hu Y, Sun Q, Omer NA and Zhao R (2018). Dietary betaine supplementation in hens modulates hypothalamic expression of cholesterol metabolic genes in F1 cockerels through modification of DNA methylation. Comparative Biochemistry and Physiology Part B: Biochemistry and Molecular Biology, 217, pp. 14-20. DOI: https://doi.org/10.1016/j.cbpb.2017.12.001.

Jiang ZR and Sim JS (1991). Egg cholesterol values in relation to the age of laying hens and to egg and yolk weights. Poultry Science, 78, $1838-1841$. DOI: https://doi.org/10.3382/ps.0701838.

Johnson ML (2013). The effect of maternal antioxidant nutrient supplementation and age on chick post-hatch innate immune function. PhD Thesis, University of Alberta. DOI: https://doi.org/10.7939/R3ST4S.

Kettunen H, Peuranen S and Tiihonen K (2001). Betaine aids in the osmoregulation of duodenal epithelium of broiler chicks, and affects the movement of water across the small intestinal epithelium in vitro. Comparative Biochemistry and Physiology, 129A:595-603. DOI: https://doi.org/10.1016/S1095-6433(01)00298-7.

Khan RU, Naz S and Abudabos AM (2017). Towards a better understanding of the therapeutic applications and corresponding mechanisms of action of honey. Environmental Science and Pollution Research, 24(36), 27755-27766. DOI: https://doi.org/10.1007/s11356-017-0567-0 .

Kidd MT, Ferket PR and Garlich JD (1997). Nutritional and osmoregulatory functions of betaine. World's Poultry Science Journal, 53:125-139. DOI: https://doi.org/10.1079/WPS19970013

Korshom M and Mandour AA (1993).Serum and yolk egg yolk cholesterol comparative study. Benha Veterinary Medical Journal (Egypt), 4: 1-6. Available at: http://agris.fao.org/agris-search/search.do?recordID=E. 
Ma D, Shan A,Chen Z, Du J, Song K, Li J and Xu Q ( 2005). Effect of Ligustrum lucidum and Schisandra chinensis on the egg production, antioxidant status and immunity Effect of Ligustrum lucidum of laying hens during heat stress. Archives of animal nutrition, 59(6):439-. DOI: https://doi.org/10.1080/17450390500353499

Ministry of Agriculture Decree (MAD) (1996). The standard properties for ingredients, feed additives and feed manufactured for animal and poultry. EL Wakaee EL-Masria, Amirria Cairo, Egypt. 192 (1997): 95.

Nelson RH (2013). Hyperlipidemia as a risk factor for cardiovascular disease. Primary Care: Clinics in Office Practice, $40(1)$, $195-211$. DOI: https://doi.org/10.1016/j.pop.2012.11.003

Padhi MK (2016). Importance of indigenous breeds of chicken for rural economy and their improvements for higher production performance. Scientifica, DOI: https://doi.org/10.1155/2016/2604685

Ratriyanto A, Mosenthin R, Bauer E and Eklund M (2009). Metabolic, osmoregulatory and nutritional functions of betaine in monogastric animals. Asian-Australasian Journal of Animal Sciences, 22(10), 1461-1476. Available at: DOI: https://doi.org/10.5713/ajas.2009.80659.

Shafey TM, Dingle JG and McDonald MW (1998). The relationships between egg yolk cholesterol, egg production and age of the hen in three Australian layer strains. Journal of the Saudi Society of Agricultural Sciences, 10: 33-41.

Surai PF (2012). The antioxidant properties of canthaxanthin and its potential effects in the poultry eggs and on embryonic development of the chick. Part 2. World's Poultry Science Journal, 68(4): 717-726. DOI: https://doi.org/10.1017/S0043933912000840.

Surai AP, Surai PF, Steinberg W, Wakeman WG, Speake BK and Sparks NHC (2003). Effect of canthaxanthin content of the maternal diet on the antioxidant system of the developing chick. British poultry science, 44:612619. https://doi.org/10.1080/00071660310001616200.

Xing J, Kang L and Jiang YL (2009). Effect of dietary betaine supplementation on mRNA expression and promoter CpG methylaiton of lipoprotein lipase gene. The journal of poultry science, 46: 224-228. DOI: https://doi.org/10.2141/jpsa.46.224.

Xing JY and Jiang YL (2012). Effect of dietary betaine supplementation on mRNA level of lipogenesis genes and on promoter CpG methylation of fatty acid synthase (FAS) gene in laying hens. African Journal of Biotechnology, 11: 6633-6640. DOI: http://dx.doi.org/10.5897/AJB11.3197.

Ylilauri MP, Voutilainen S, Lonnroos E, Mursu J, Virtanen HE, Koskinen TT and Virtanen JK (2017). Association of dietary cholesterol and egg intakes with the risk of incident dementia or Alzheimer disease: the Kuopio Ischaemic Heart Disease Risk Factor Study. The American Journal of Clinical Nutrition, 105(2), 476-484. DOI: https://doi.org/10.3945/ajcn.116.146753.

Zeisel SH, Mar MH, Howe JC and Holden JM (2003).Concentrations of choline-containing compounds and betaine in common foods. The Journal of nutrition, 133(5): 1302-1307. DOI: https://doi.org/10.1093/jn/133.5.1302.

Zemková L', Simeonovová J, Lichovníková M and Somerlíková K (2007). The effects of housing systems and age of hens on the weight and cholesterol concentration of the egg. Magnesium (g/kg). Czech Journal of Animal Science. 52 (4): 110-115. DOI: https://doi.org/10.17221/2269-cjas.

Zhang W, Zhang K Y, Ding X M, Bai S P, Hernandez J M, Yao B and Zhu Q (2011). Influence of canthaxanthin on broiler breeder reproduction, chick quality, and performance. Poultry Science. 90:1516-152. Available at: https://doi.org/10.3382/ps.2010-01126.

Zhang M, Zhang H, Li H, Lai F, Li X, Tang Y, Min T and Wu H (2016). Antioxidant Mechanism of Betaine without Free Radical Scavenging Ability. Journal of agricultural and food chemistry, 64:7921-7930. DOI: https://doi.org/10.1021/acs.jafc.6b03592.

Zou X T, Ma Y Land Xu ZR (1998). Effects of betaine and thyroprotein on laying performance and approach to mechanism of the effects in hens. Acta Agriculturae Zhejiangensis, 10:144-149. Available at: http://en.cnki.com.cn/Article_en/CJFDTOTAL-ZJNB803.007.htm 